it, a stratum thick enough for the radiation of the gas to overpower the fierce glare of the photosphere behind it, and both these views have been shown to be untenable.

December 2I

\section{R. Meldola}

\section{Oxygen in Sea-water}

AT p. 267 of the second volume of the "Voyage of the Challenger," Sir Wyville Thomson writes:-

"Mr. Buchanan drew the conclusion in explanation of the small amount of oxygen at depths of 300 fathoms and upwards, 'that animal life must be particularly abundant and active at this depth, or at least more abundant than at greater depths,' In other words, that a permanent condition, probably of all con. ditions the most unfavourable to animal life, is produced and maintained by its excess."

"This is entirely contrary to experience."

The words in inverted commas are part of a sentence in a sliort report in NATURE (vol. xvi. p. 255), of a paper which I read before the Royal Society of Edinburgh, on the results of the analysis of so many of the samples of air extracted during the cruise, from sea-water of different sources, as I was able to accomplish before my connection with the work of the expedition ceased. I will not encroach on your valuable space by anticipating the discussion of the bearing of my observations and those of others on the question of the greater or less abundance of animal life at different depths in the sea; but as the above quotation, from its fragmentary character, is somewhat misleading, both as to the nature of the belief which I expressed and my grounds for holding it, I must ask you to give place to the concluding sentences of the above report:-

"It is evident from these figures 1 that between 200 and 400 fathoms there is a great consumption of oxygen going on, and, as it is difficult to conceive its being consumed otherwise than by living creatures, the conclusion is forced on us that animal life must be particularly abundant and active at this depth, or, at least, ruore abundant than at greater depths; for at less depths there is more opportunity for renewal of the oxygen by reason both of the greater proximity to the surface and of the existence of vegetable life. This conclusion was borne out by the numerous experiments made by Mr. Murray with the tow-net at intermediate depths, which went to prove the existence of abundance of animal life down to 400 fathoms, vegetable life never extending to much below roo fathoms. Below 400 fathoms life is sparingly met with."

It will be seen that the only independent experience which $\epsilon$ ists, namely, Mr. Murray's observations with the tow-net at different depths, is in favour of the conclusion at which I arrived.

IO, Moray Place, Edinburgh, December I3 J. Y. BUCHANAN

\section{On some Peculiar Points in the Insect-Fauna of Chili}

For some years past I have been particularly interested in some points in the entomology of Chili and the extreme southern portion of South America, which, although known to most entomologists who have made special groups their study, have never yet been, so far as I know, even more than casually alluded to in works on geographical distribution, and are ignored in the principal ones. I allude to the occurrence in that part of the world of well-marked palæarctic or nearctic forms not found otherwise in America south of Mexico, and utterly unknown in the southern hemisphere in the Old World.

$I$ have collected a not inconsiderable amount of data concerning this subject, and have the intention of addressing a circular to zoologists and also to botanists, fasking for further information.

I will here allude to such familiar genera as Carabus amongst beetles and Argynnis and Colias amongst butterflies. Carabus is very abundant in species in the palrearctic region, poor in the nearctic, and reappears (for the whole world) only in Chill. The distribution of Argynnis and Colics is similar, only that they are about equally abundant in the two northern regions, and of Colias it appears probable that a single species occurs in Peru, but this exception only proves the rule.

In the Trichoptera, or Caddis-flies, a group of insects in which I am especially interested, there is even a still more striking case. The typical family, Limnophilida, comprising those insects the larvæ of which manufacture the cases of twigs and straws, so

* A table of the mean amounts of oxygen in a hundred parts of oxygen and nitrogen contained in waters from different depths abundant in our ponds and ditches, and which is so rich in species in northern regions, is not, with the exception stated below, known south of Mexico in the New World nor south of the Himalayas in the Old; but I have several species from Chili, Araucania, and the Falkland Isles.

I could already multiply parallel instances, but have said enough to prove my case.

Confessedly I have, at present, only crude theoretical notions on the causes of this anomalous distribution. It might be said that these insects are the remains of a former Antarctic glacial epoch. But if this be so, then we must presuppose the existence of former Arctic and Antarctic faunas similar in details; all other evidence tends, I think, to disprove this. It may truly be said that, owing to the non-existence of large tracts of land towards the south pole at all comparable with those that exist towards the north, we are not in a position to acquire sufficient data, yet we have the continent of Australia and the large islands of New Zealand extending somewhat far south, and they furnish us with no indication whatever of forms parallel with those found in Chili.

It has occurred to me as just possible, that at the conclusion of the northern glacial epoch a few stragglers, instead of wending their way northward, mistook the points of the compass and went south ward. But there remains this great difficulty, viz., that, with one possible exception, there are no indications of these forms on the northern portions of the Andes of Scuth America.

I call attention to this subject as one deserving far more consideration than it has hitherto received, and with the idea that, by ventilating it in NATURE, I may receive additional information on a point that greatly interests me.
39, Limes Grove, Lewisham
R. MCLACHLAN

\section{Arctic Auror}

IT will probably interest some of your readers to know that in reply to a communication lately addressed by me to the Admiralty I am informed that Captain Sir George Nares reports that although the auroral glow was observed on several occasions between October 25, 1875, and February 26, 1876, true auroræ were seldom observed, and the displays were so faint and lasted so short a time that the spectroscopic results were not considered worthy of a special report. Although the citron line was seen occasionally, on only two occasions was it well defined, and then for so short a time that no measure could be obtained. A report is preparing with a view to compare the auroral displays with magnetic disturbance, meteorological changes, and other phenomena which will include the few spectroscopic observations obtained. J. RAND CAPRON

Guildown, December 24

\section{Insects and Artificial Flowers}

IN a late number of NATURE a short account is given of some experiments recently made by Prof. J. Plateau, of Ghent, as to insects being deceived by artificial flowers. The nature of these experiments is not given, but the result would appear to have been of a somewhat negative character. In connection with the subject the following incident will not, I think, be considered uninteresting. I was coming by one of the lake steamers from Como to Menaggio, in September, 1875, and saw a humming-bird hawk moth, Macroglossa stellatarum, fly to some bright-coloured flowers on a lady's hat on deck, and hang, poised over them for a short time, and then fly away. During the process it made one of those short familiar darts off, for a moment, and then returned, after the manner of the moth when disturbed, and it remained long enough to convince me that it had tested the flowers and found them wanting. Another incident comes across my mind while writing this, which, though it does not exactly bear upon the point, yet is of a somewhat kindred nature. I was crossing from Harwich to Antwerp in August of the same year, and as the weather was fine, and the boat crowded, I remained on deck all night. About 4 o'clock in the morning I saw what appeared to be a bird or a bat flying rapidly about the rigging. As $I$ was watching it the funnel of the steamer poured forth a thick column of black smoke, owing to the iresh coaling it had just received. Off went the creature as soon as it perceived the change, or, at all events, as soon as the change took place, and flew for some time in and about the smoke, now darting through it, close to the funnel mouth, and then letting itself be borne along with it, for some distance, as if in sport, looking very strange and weirdlike in the process, 